\title{
Fossil Seed from the Miocene Shihti Formation of Taiwan
}

\author{
Zhi-Cheng Lin ${ }^{1,2}$, Andrew Tien-Shun Lin ${ }^{1, *}$, Shun-Wen Yu ${ }^{3}$, Tai-Ping Liao ${ }^{2}$, and Gui-Wen Xu ${ }^{2}$ \\ ${ }^{1}$ Department of Earth Sciences, National Central University, Jhongli, Taiwan \\ ${ }^{2}$ School of Petroleum and Natural Gas Engineering, Chongqing University of Science and Technology, Chongqing, China \\ ${ }^{3}$ Graduate Institute of Applied Geology, National Central University, Jhongli, Taiwan
}

Received 12 July 2012, accepted 11 March 2013

\begin{abstract}
A compressed fossil seed, described as Carpolithes sp., is found in the coal-bearing Miocene Shihti Formation from the Lifeng coal mine, Sanshia District of the New Taipei City. The fossil is generally rounded with a diameter of ca. $10 \mathrm{~mm}$ in lateral view. The anatomical features of the testa epidermal cells were observed using anatomical analysis. The anatomical features of the megafossil organ from the Formation are reported for the first time.
\end{abstract}

Key words: Carpolithes, Fossil seed, Testa, Miocene, Shihti Formation

Citation: Lin, Z. C., A. T.-S. Lin, S. W. Yu, T. P. Liao, and G. W. Xu, 2013: Fossil seed from the Miocene Shihti Formation of Taiwan. Terr. Atmos. Ocean. Sci., 24, 731-735, doi: 10.3319/TAO.2013.03.11.01(TT)

\section{INTRODUCTION}

The Miocene Shihti Formation is the most important coal-bearing strata in Taiwan (Ho 1966, 1988). It is encased by two marine fossil-bearing Miocene formations, the overlying Nankang Formation and the underlying Taliao Formation (Fig. 1a). The age of the Shihti Formation is inferred as Middle Miocene based on planktonic foraminiferal zones in the Nankang and Taliao Formations (Ho 1966; Chaney and Chuang 1968). The Shihti Formation consists mainly of light gray sandstone, whitish gray siltstone, and dark gray shale with a number of coal beds or coal seams. The Formation is subdivided into two members, the upper Szechiaoting Member and the lower Patoutze Member (Ho 1966). The Patoutze Member is composed mainly of three massive, white and very thick sandstone beds intercalated with dark or laminated shale layers. Coal beds have been found at several horizons but only one seam is minable. The Szechiaoting Member is characterized by more coal beds than in the Patoutze Member, while white sandstone beds are less frequent and thinner in thickness compared to the Patoutze Member. The shale and siltstone inter-laminations or fine-grained sandstone are well developed. Most of the fossil plants are preserved in this member.
The first palaeobotanical study of the Shihti Formation was published in 1968 (i.e., Chaney and Chuang 1968). Many leaf impressions were found from the Shihti Formation in today's Sanshia District, New Taipei City. Ferns, a conifer and members of nineteen genera in twelve families of angiosperms, including three new species (Coniogramme devoli, Perrotetia miocenica, and Acer juani), were identified (Chaney and Chuang 1968). However, all of the identified fossils are impressions with no fossil microstructures preserved. Canright (1972) found and reported on carbonized compressions of leafy branches, a single ovulate cone of Metasequoia, and many taxodiaceous pollen grains from the Shihti Formation. The study of macrofossils, however, still rests heavily upon morphological descriptions. Liu and Zheng (1995) inferred the paleoclimate with a technique called "Leaf Margin Analysis" (LMA) based on fossils reported by Chaney and Chuang (1968). Since then, very few studies have been carried out on the flora of the Shihti Formation except for some reports for the general public (e.g., Li and Chuang 2000). The latest report to mention the Shihti flora was a review, which briefly compared all of the published megafossil leaves of the Shihti flora in the northern part of Taiwan with those of the Lilongshan flora (the Late Miocene) in the southern part of Taiwan (Uemura and $\mathrm{Li}$ 2006).

\footnotetext{
* Corresponding author

E-mail:andrewl@ncu.edu.tw
} 
(a)

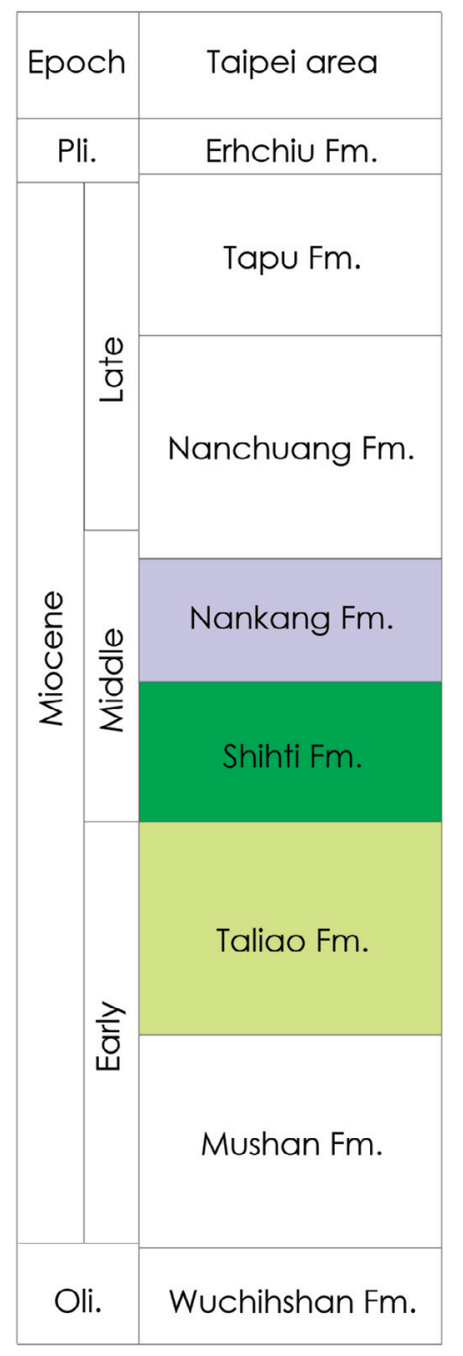

(b)

(c)

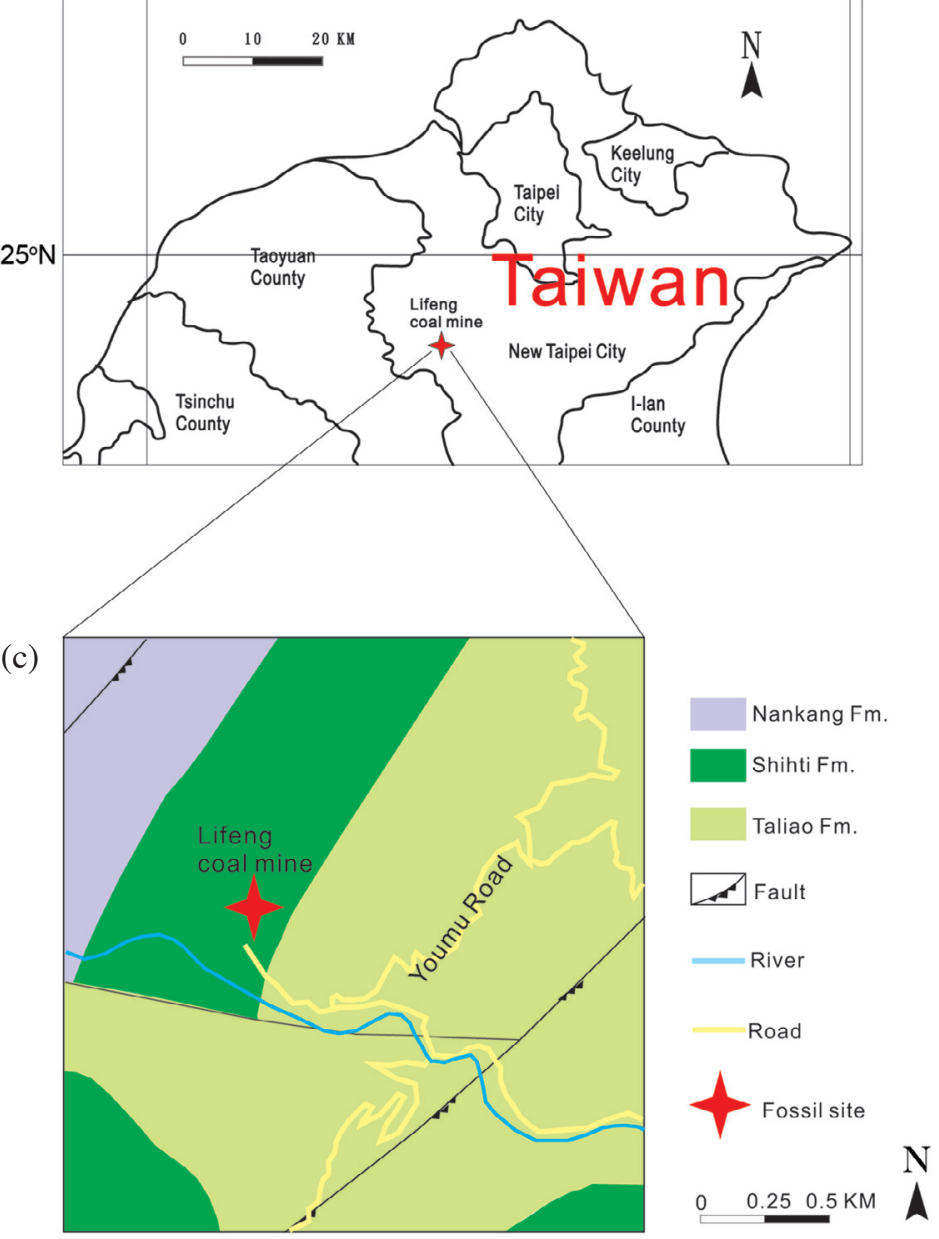

Fig. 1. (a) A stratigraphic table of the Miocene in the Taipei area. (b) A map showing northern Taiwan with the Lifeng coal mine marked as a red star, where the studied fossils are collected. (c) Geological map in and around the Lifeng coal mine. The fossil site lies at the Shihti Formation and the geological map and stratigraphic table are revised from Hu and Mao (1996). Abbreviations: Fm: Formation, Pli: Pliocene, Oli: Oligocene.

Here, we report on a newly found compressed fossil reproductive remain from the Miocene Shihti Formation. The well preserved morphological and anatomical features of the fossil are observed. The anatomical features of the megafossil organ are reported for the first time from the Formation.

\section{MATERIALS AND METHODS}

The fossil seed was collected from the Lifeng coal mine in the Sanshia District, New Taipei City $\left(24.87^{\circ} \mathrm{N}\right.$, $121.40^{\circ} \mathrm{E}$ ) (Figs. $1 \mathrm{~b}$ and c). The fossils were found in the laminated, gray to dark gray shale, siltstone, and coaly stringers of the Szechiaoting Member, Shihti Formation. The fossil seed was found with counterparts and some fossil leaves were also found from the same bed, such as Gramineae, Fagaceae, Lauraceae, Aceraceae, Salicaceae and Euphorbiaceae.
The recovered specimens were photographed in the field with a 1000 megapixel Panasonic DMC-LX5 digital camera and in the lab with a Leica S8AP stereomicroscope. Because the fossils were embedded in the dark gray siltstone with very little contrast, they were immersed in the water to enhance the contrast during photography (Figs. 2a and $b)$. The body fossil is clearer than its counterpart, but the counterpart is more complete. The body fossil was coated with carbon and observed with a field-emission Scanning Electron Microscope (SEM) of JEOL JSM-7000F in the Department of Earth Sciences, National Central University, Taiwan. We then sampled a piece of the seed with a scalpel to digest with an attempt to resolve its microstructures. Procedures for the digesting method are as follows. Samples were immersed in $10 \%$ concentration $\mathrm{HCl}$ solution to remove calcium carbonate for 8 hours. HF solution at $50 \%$ concentration was then used for 12 hours to dissolve silicate minerals. After washing with distilled water, the samples 


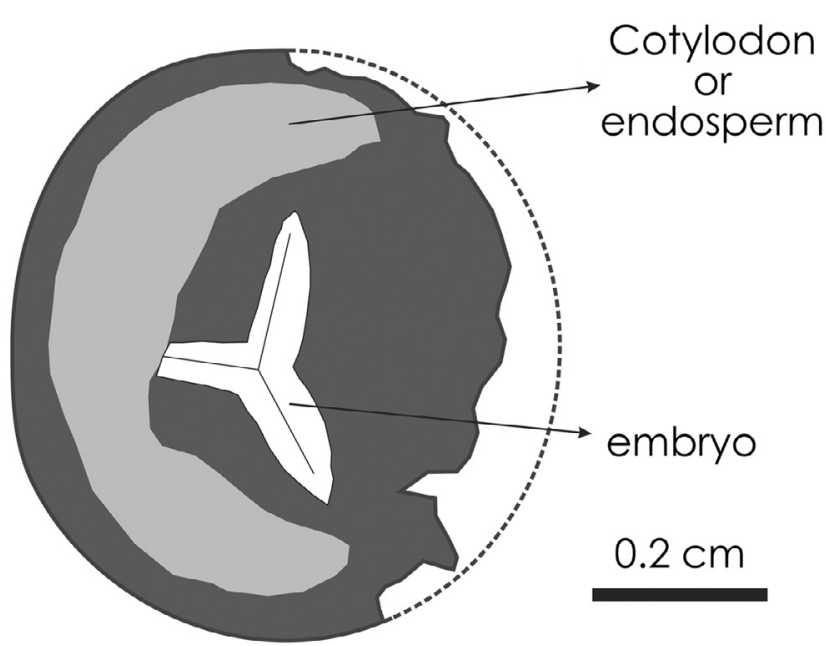

Fig. 2. Sketches based on the part of the fossil seed shown in Fig. 3a with interpretations of the morphological structures.

were oxidized in Schultz's solution $\left(\mathrm{HNO}_{3}: \mathrm{KClO}_{3}=3: 1\right)$ for 8 to10 hours. When the black color of the samples changed to dark or light-brown color, the samples were removed and then neutralized using $0.1 \% \mathrm{NH}_{4} \mathrm{OH}$ solution for $10 \mathrm{~min}$ utes. After washing with distilled water, the samples were divided into two halves, one for the Optical microscopy (OM) observation, the other half for scanning electron microscopy. The sample for OM was stained in a $0.5 \%$ Safranin solution and mounted on slides, embedded in glycerine jelly and photographed under an optical microscope (Leica DMLP). The samples for SEM were mounted on a stub and coated with carbon and observed with the SEM of JEOL JSM-7000F. Some of the terminology follows those of Rudall (2006) and Linkies et al. (2010). The fossil and slides are housed in Basin Research Group, Department of Earth Sciences, National Central University.

\section{RESULTS AND DISCUSSION}

\subsection{Description of the Fossil: Carpolithes Brongniart and Carpolithes sp.}

The part and counterpart of the seed specimen are shown in Figs. 3a and b. The fossil seed is generally rounded with a diameter of ca. $10 \mathrm{~mm}$ in lateral view. The seed coat is thin-walled, about $20-30 \mu \mathrm{m}$ thick (Fig. 3c). The heart-shaped outthrust in the middle part is interpreted as the shape and position of the embryo (Fig. 2) (Rudall 2006). The crescent-shaped outthrust aside the embryo is interpreted as the shape and position of the endosperm or cotyledon (Fig. 2).

The internal seed tissues are not preserved (Fig. 3d). The anatomical structures of the fossil seed coat are illustrated in Figs. 3c to i. The whole seed coat seems to be composed of three layers, with layer 1 cuticularized (Figs. 3c and e). Most of the epidermal cells of the testa are elongated and some are polygonal, 26 - $67 \mu \mathrm{m}$ long (average $46 \mu \mathrm{m}, \mathrm{n}$ $=20$ ) and $4-12 \mu \mathrm{m}$ wide (average $7 \mu \mathrm{m}, \mathrm{n}=20$ ). The cells are arranged in parallel groupings. No stomata, trichomes or any other accessories are observed (Figs. 3e to i).

\subsection{Discussion}

Seeds preserved as compression fossils provide good material for anatomical analysis. Although the internal tissues of our fossil are not preserved (Fig. 3d), the anatomical features of the seed coat were revealed with the help of scanning electron microscopy (SEM). They can at least prove that anatomical structures of some megafossils from the Shihti Formation can be preserved. However, it is difficult to find sufficient diagnostic features in this specimen to place the fossil phylogenetically. We, therefore, classify it as Carpolithes sp.

Chaney and Chuang (1968) identified 21 species in 20 genera of plant leaves (ferns and angiosperms) from the Shihti Formation, but all are impressions. The only reproductive organ reported from this formation is an ovulate cone of Metasequoia (gymnosperm), with only a morphological description (Canright 1972). Plant reproductive organs are normally preserved more poorly than vegetative organs, but the former are very useful in systematic work and in studying plant evolution (Linkies et al. 2010). Fossil plants from other regions have been successfully identified based on seed and fruit characteristics (e.g., Stockey and Pigg 1991; Manchester 1994, 2011; Wang et al. 2007; Gong et al. 2010; Manchester et al. 2012). Seed anatomical features, especially the seed coat characteristics, are useful for identifying extant and extinct plants (van Bergen et al. 1994a, b; Doweld 1998; Sukhorukov 2008; Zhao and Li 2008).

The extant flora of Taiwan comprises ca. 3600 species in more than 1200 genera, of which $29.3 \%$ of the species and four genera are endemic to Taiwan (ECFT 1975 - 1979; Ying and Hsu 2002). It is important to study and reconstruct the fossil flora to understand the origin and evolution of extant flora and even the geological history of Taiwan Island. The research on the megafossil flora of Taiwan is obviously insufficient. Only two floras were relatively well-studied in the floral composition (Uemura and Li 2006). The taxa identified from these floras are also few. Only 22 species within 21 genera of 14 families of the Shihti flora in northern Taiwan and 26 leafy species and 7 seed species of 4 genera within the Lilongshan flora in southern Taiwan were recognized prior to this study (Chaney and Chuang 1968; Canright 1972; Li 2000; Uemura and Li 2006). Nearly all of the previously studied fossils are impressions with only morphological descriptions. Therefore, more paleobotanical works should be carried out to understand the extinct and extant flora of Taiwan. 

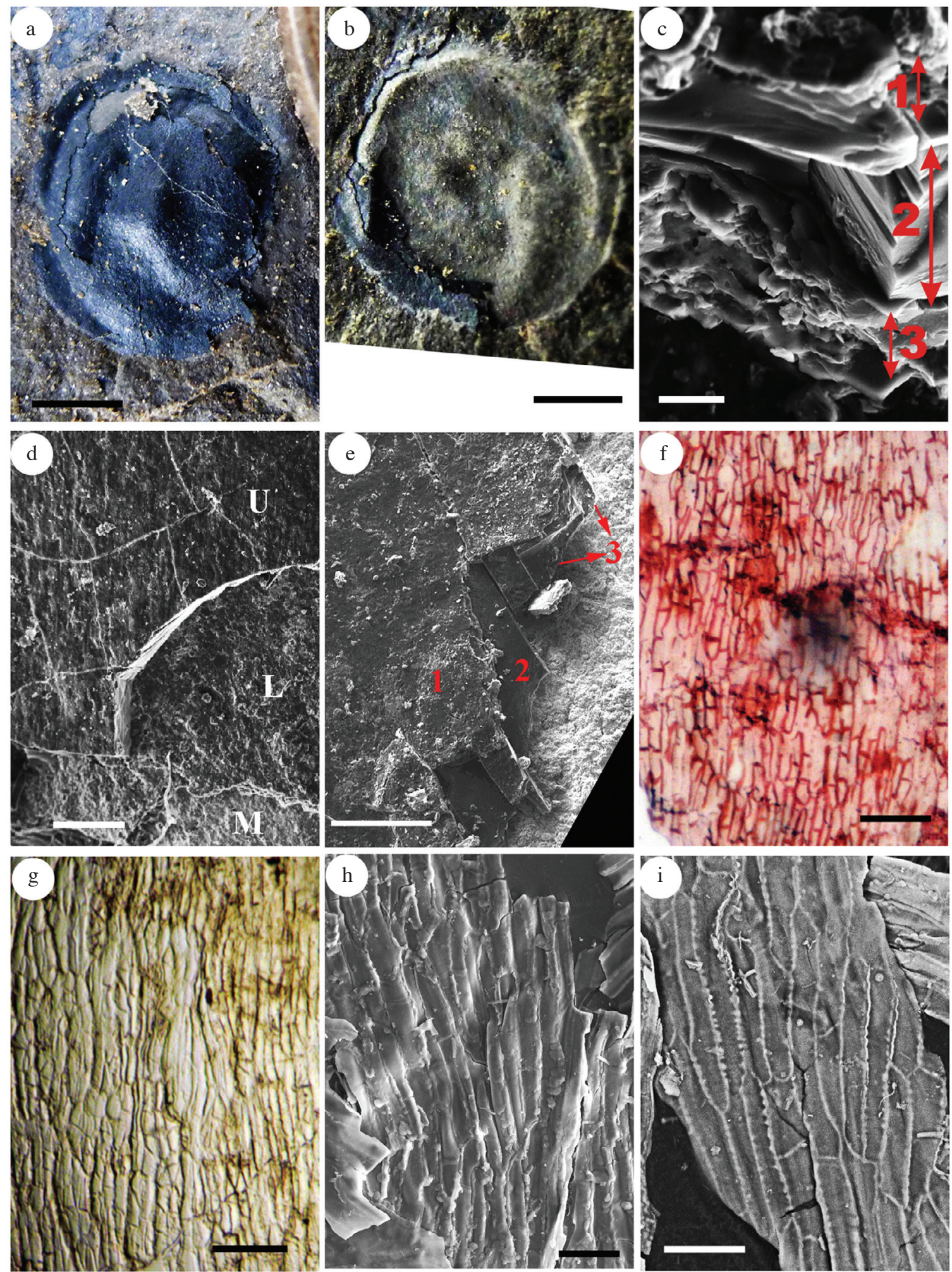

Fig. 3. Various images for the studied fossils under optical microscope and SEM. (a) Part of the fossil specimen, scale bar $=0.2 \mathrm{~cm}$; (b) counterpart of the fossil specimen, scale bar $=0.2 \mathrm{~cm}$; (c) cross section of the whole seed coat under scanning electron microscope $(\mathrm{SEM})$, scale bar $=5 \mu \mathrm{m}$; 1, 2, 3 marks three layers from the outside consisting of the testa; (d) upper and lower pieces of the whole seed coat from the part of the specimen (a) under SEM, scale bar $=100 \mu \mathrm{m}$; U: outer surface of the upper side of the seed coat; L: inner surface of the lower side of the seed coat; M: rock matrix; (e) A natural fracture of the seed coat showing the three compositing layers; 1, 2, 3 marks three layers from the outside consisting of the testa; (f) epidermal cells under the optical microscope $(\mathrm{OM})$ after being stained with safranin, scale bar $=50 \mu \mathrm{m}$; $(\mathrm{g})$ epidermal structures under OM without staining, scale bar $=50 \mu \mathrm{m}$; (h) external surface of the epidermis under SEM, scale bar $=50 \mu \mathrm{m}$; (i) internal surface of the epidermis under SEM, scale bar $=20 \mu \mathrm{m}$. 
Acknowledgements We thank Mr. Yi-Tai Chi, National Central University, for SEM assistance. This research is funded by the Aim for the Top University Project, Ministry of Education, Taiwan; National Natural Science Foundation of China (grant No. 41202001); the Science and Technology Research Project of Chongqing Education Committee (grant No. KJ121406); the National Major Projects (grant No. 2011ZX05005-002-009HZ); and the Teaching and Scientific Research Project of CQUST (grant Nos. 201216 and 201142). We also thank Prof. Steven R. Manchester and two anonymous reviewers for reviewing the paper and giving many useful suggestions.

\section{REFERENCES}

Canright, J. E., 1972: Evidence of the existence of Metasequoia in the Miocene of Taiwan. Taiwania, 17, 222228.

Chaney, R. W. and C. C. Chuang, 1968: An Oak-Laurel forest in the Miocene of Taiwan. Proc. Geol. Soc. China, 11, 3-18.

Doweld, A. B., 1998: Carpology, seed anatomy and taxonomic relationships of Tetracentron (Tetracentraceae) and Trochodendron (Trochodendraceae). Ann. Bot., 82, 413-443.

Gong, F., I. Karsai, and Y. S. C. Liu, 2010: Vitis seeds (Vitaceae) from the late Neogene Gray Fossil Site, northeastern Tennessee, U.S.A. Rev. Palaeobot. Palynology, 162, 71-83, doi: 10.1016/j.revpalbo.2010.05.005. [Link]

Ho, C. S., 1966: The Shihti Formation in Northern Taiwan. Bull. Geol. Surv. Taiwan, 17, 1-25.

Ho, C. S., 1988: An Introduction to the Geology of Taiwan, Explanatory Texts of the Geologic Map of Taiwan (Second Edition), Central Geological Survey, Taipei, 192 pp.

Hu, J. K. and E. W. Mao, 1996: Geological Map of Taiwan of Scale 1:50000, Sheet No. 8: Taoyuan and Explanation Notes, Central Geological Survey, Taipei.

Li, C. Y., 2000: A study on Miocene floras in Taiwan, Ph.D. Thesis, National Chung Hsing University, Taichung, Taiwan, 1-115. (in Chinese)

Li, C. Y. and W. S. Chuang, 2000: Serial reports on fossil flora of Taiwan (1 7), Research Brief of Natural Science Museum, 165-176. (in Chinese)

Linkies, A., K. Graeber, C. Knight, and G. Leubner-Metzger, 2010: The evolution of seeds. New Phytol., 186, 817 831, doi: 10.1111/j.1469-8137.2010.03249.x. [Link]

Liu, Y. S. and Y. H. Zheng, 1995: Neogene floras. In: Li, X. X. (Ed.), Fossil Floras of China Through the Geological Ages (English edition), Guangdong Science and Technology Press, Guangzhou, China, 506-551.
Manchester, S. R., 1994: Fruits and Seeds of the Middle Eocene Nut Beds flora, Clarno Formation, Oregon (Palaeontographica Americana), Paleontological Research Institute, $205 \mathrm{pp}$.

Manchester, S. R., 2011: Fruits of ticodendraceae (fagales) from the Eocene of Europe and North America. Int. J. Plant Sci., 172, 1179-1187, doi: 10.1086/662135. [Link]

Manchester, S. R., I. Chen, and T. A. Lott, 2012: Seeds of Ampelocissus, Cissus, and Leea (vitales) from the paleogene of western Peru and their biogeographic significance. Int. J. Plant Sci., 173, 933-943, doi: 10.10 86/667233. [Link]

Rudall, P. J., 2006: Anatomy of Flowering Plants: An Introduction to Structure and Development (Third Edition), Cambridge University Press, 158 pp.

Stockey, R. A. and K. B. Pigg, 1991: Flowers and fruits of Princetonia allenbyensis (Magnoliopsida; family indet.) from the Middle Eocene Princeton chert of British Columbia. Rev. Palaeobot. Palynology, 70, 163-172, doi: 10.1016/0034-6667(91)90084-G. [Link]

Sukhorukov, A. P., 2008: Fruit anatomy of the genus Anabasis (Salsoloideae, Chenopodiaceae). Aust. Syst. Bot., 21, 431-442, doi: 10.1071/SB08013. [Link]

Uemura, K. and C. Y. Li, 2006: Miocene floras of Taiwan: An overview in comparison with those of southwestern end of Japan. Men. Natn. Sci. Mus., Tokyo, 44, 185193.

van Bergen, P. F., M. E. Collinson, P. G. Hatcher, and J. W. de Leeuw, 1994a: Lithological control on the state of preservation of fossil seed coats of water plants. Org. Geochem., 22, 683-702, doi: 10.1016/0146-6380 (94)90133-3 . [Link]

van Bergen, P. F., M. E. Collinson, J. S. S. Damsté, and J. W. de Leeuw, 1994b: Chemical and microscopical characterization of inner seed coats of fossil water plants. Geochim. Cosmochim. Acta, 58, 231-239, doi: 10.1016/0016-7037(94)90460-X. [Link]

Wang, Y. G., G. Z. Li, W. J. Zhang, J. You, and J. K. Chen, 2007: A systematic study of the genus Rhododendron (Ericaceae) using micromorphological characters of fruit surface and seed coat. Acta Phytotaxon. Sin., 45, 21-38. (in Chinese)

Ying, T. S. and K. S. Hsu, 2002: An analysis of the flora of seed plants of Taiwan, China: Its nature, characteristics, and relations with the flora of the mainland. Acta Phytotaxon. Sin., 40, 1-51. (in Chinese)

Zhao, L. C. and D. Y. Li, 2008: Anatomically preserved seeds of Corylopsis (Hamamelidaceae) from the Miocene of Yunnan, China, and their phytogeographic implications. Int. J. Plant Sci., 169, 483-494, doi: 10.10 86/526461. [Link] 